\title{
Comment
}

Neuroepidemiology 2011;37:107-108

DOI: $10.1159 / 000331234$

\section{On the Prevalence of Multiple Sclerosis in Serbia}

John F. Kurtzke

Department of Neurology, Georgetown University, Washington, D.C., USA

In their fine article, Toncev et al. [1] presented the results of their epidemiological study on the prevalence of multiple sclerosis in a circumscribed region of central Serbia, just south of Belgrade. In order to place this work in context, we need perhaps to recall what this science is about.

'In these considerations lie the germs of a science, which, in an ideally complete form, would furnish a medical history of mankind [and] will give: firstly, a picture of the occurrence, the distribution, and the types of the diseases of mankind, in distinct epochs of time, and at various points of the earth's surface; and, secondly, will render an account of the relations of these diseases to the external conditions surrounding the individual and determining his manner of life. And this science I have named, from the dominating point of view, the science of geographical and historical pathology.'

Thus spake (in translation) August Hirsch of Berlin [2]. This new field was intended to answer the reporter's questions of in whom, when and where a disorder (the what) was to be found, with the ultimate hope of finding its cause (the why). 'Geographical pathology', however, seemed not to have generally replaced (but see References) the term 'epidemiology', introduced somewhat earlier with the definition of 'that branch of medical science which treats of epidemics', according to the Oxford Universal Dictionary of 1955. That source indicated the word 'epidemic' was introduced into English as an adjective in 1603 and a noun in 1757, soon to replace the term 'epidemy' of 1472 . This in turn had arisen via Old French 'ypidíme' from Latin 'epidemia' and Greek

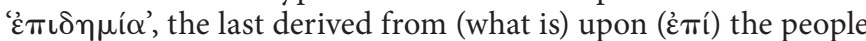
( $\delta \tilde{\eta} \mu \mathrm{os})$. All these terms referred to the acute occurrence of an untoward event, usually an illness, newly experienced in a population - long before the germ theory.

A Society of Neurological Epidemiology had been formed in 1965 by Leonard Kurland, then at Mayo Clinic, Milton Alter of Minnesota and John Kurtzke in Washington, with some deliberation as to which word was to be the noun. This was solved by their coinage of 'neuroepidemiology', when in 1967 they became the first officers of the new section of that name within the American Academy of Neurology. There were still some qualms as to the need for a hyphen, lest our British cousins transformed it into a diphthong like in œdema. Our journal, however, was not founded until 1982, when Kurland's successor as head of neuroepidemiology at the NINDB (National Institute of Neurological Dis- eases and Blindness), NIH, Bruce Schoenberg, became its first editor. After Bruce came Milt Alter as editor, and the journal was well on its way to its current status as the leading publication in the field. And throughout its existence, studies on multiple sclerosis have played a prominent role.

Opinions as to the value of an epidemiologic view of the enigma that is multiple sclerosis have varied from vehement opposition to fervent conviction, while most laborers in the vineyard seem to have looked on the field with more or less benign neglect. One approach, which is my background and bias, arises out of the physician-patient relationship. The physician's prime duty is to help his patient. This requires a correct diagnosis as a prelude to proper treatment. The neurologist in particular needs to use all available information from detailed examination, complete history and whatever laboratory values might help him to decide what is wrong with the patient. Physicians have always practiced 'individualized medicine' which should be 'data driven' and 'evidence based', to use the jargon of the day. They need to find what the patient really has - not what they think he should have. This approach may be summarized as LPG: L for localization - where is the lesion; P for paranoia - do not trust others' findings, do your own examination, and G for GIGO (garbage in, garbage out) - wrong findings, wrong diagnosis. This is also the medical approach to epidemiology: LPG pertains, except L means 'where are the cases', $\mathrm{P}$ is 'do your own analyses' (even if as a reader rather than as an author), and G is 'wrong/inadequate findings, wrong conclusions'.

Epidemiologically, the history and physical examination are the distributions in time and space. Cases derived from one practice or hospital should not be extrapolated to the whole community, any more than two knee jerks and gait speed define the examination. This is well recognized in epidemiological circles as input bias. But can the results of one community be extrapolated to the whole state or province? Can one province define the entire country? Can results in 1960 be taken as valid for 2010? Interpretations of distributions should be based on the findings, and not on what the author believes they should be.

Of the 500 or so community-based prevalence studies, there is only one published before World War II, that by Allison in 1931 for north Wales [3], joined by but three nationwide assessments based on known cases: by Sällström [4] for Sweden (1925-1934), by Gram [5] for Denmark (1921-1933), and by Bing and Reese [6] and Ackermann [7] for Switzerland (1918-1922). The first of these, with a highly significant concentration of cases in south-central Sweden, set the stage for later interpretations of a north-south gradient of multiple sclerosis in Europe. This had been loosely confirmed into the 1980s, but since then there has been a notable diffusion so that Southern Europe has clearly joined the high-frequency region of Europe, now including the Balkans, as Toncev et al. [1] have shown. Multiple sclerosis is clearly a spreading disease, both within and across continents, a situation which is explicable, to me, only by the presence of a similarly distributed environmental agent [8].

\section{KARGER}

Fax +41613061234 E-Mail karger@karger.ch www.karger.com
(C) 2011 S. Karger AG, Base

0251-5350/11/0372-0107\$38.00/0 


\section{References}

1 Toncev G, Miletic Drakulic S, Knezevic Z, Boskovic Matic T, Gavrilovic A, Toncev S, Drulovic J, Pekmezovic T: Prevalence of multiple sclerosis in the Serbian District of Sumadija. Neuroepidemiology 2011;37:102106.

2 Hirsch A: Handbook of Geographical and Historical Pathology, trans from German ed 2 (by Creighton C). London, New Sydenham Society, 1883, vol. 1: Acute Infective Diseases, pp 1-2.

3 Allison RS: Disseminated sclerosis in north Wales. An inquiry into its incidence, frequency, distribution and other ætiological factors. Brain 1931;53:391-430

4 Sällström T: Das Vorkommen und die Verbreitung der multiplen Sklerose in Schweden: Zur geographischen Pathologie der multiplen Sklerose. Acta Med Scand 1942;(suppl 137):1-141.

5 Gram HC: Den disseminerede skleroses forekomst i Danmark. Ugeskr Læger 1934;96:823-825.
6 Bing R, Reese H: Die multiple Sklerose in der Nordwestschweiz (Kantone Basel, Solothurn, Aargau, Luzern). Schweiz Med Wochenschr 1926;56:30-34.

7 Ackermann A: Die multiple Sklerose in der Schweiz: Enquete von 191822. Schweiz Med Wochenschr 1931;61:1245-1250.

8 Kurtzke JF: Epidemiology and etiology of multiple sclerosis. Phys Med Rehabil Clin N Am 2005;16:327-349.

John F. Kurtzke, MD, FACP, FAAN

7509 Salem Road

Falls Church, VA 22043-3240 (USA)

Tel. +1 7035606016

E-Mailkurtzke2@aol.com 